\title{
Different Moisture Contents of Tempered Hulled and hull-less Barley Grains Prior to Milling
}

\section{Effect on Extraction Rate, Color and Characteristics of Flours}

\author{
Abdel-Gawad, A.S.; M.K.E. Youssef; S.H.Abou-Elhawa and A.M. Abdel-Rahaman \\ Department of Food Science and Technology, Faculty of Agriculture, Assiut University
}

Received on: 3/11/2016

Accepted for publication on: 19/11/2016

\begin{abstract}
The purpose of this work was to study the effect of different moisture contents $(12,14,16$ and $18 \%)$ of conditioned hulled and hull-less barley grains prior to milling on extraction rate, color and characteristics of flours. Flour extraction rate was decreased as the tempering moisture of grains prior to milling increased. In all conditioning treatments, the flour yield was lower in hulled than in hullless variety. The flour color was significantly improved (become white) as the conditioning moisture of hull-less barley grains before milling increased, while the hulled barley showed slight improving. The chemical composition of flours including protein, fat, crude fiber, ash, pentosan, $\beta$-glucan, bond and total phenolic compound and phytic acid contents showed decreasing, whereas starch, reducing sugar and free phenolics contents were raised as the conditioning moisture of grains prior to milling in both varieties increased. A slight raise in solubility of protein and starch with substantially increasing in the solubility of pentosan and $\beta$-glucan was observed in all flours from both barley varieties as the tempering moisture of grains before milling increased. The solubility of $\beta$-glucan was higher in flours from hulled than that corresponding flours from hull-less variety and this reflected the higher values of relative viscosity of flour water extract from the former than the latter. The Rapid Visco Analyser (RVA) measurements for the flours obtained from hull and hull-less barley indicated that the values for pasting temperature, time to gelatinization, time to peak, peak viscosity, trough viscosity and final viscosity were decreased as the moisture content of barley grains prior to milling increased.
\end{abstract}

Keywords: hulled, hull-less, barley, tempering, milling, flour, extraction rate, color, pentosan, $\beta$-glucan, phenolics, phytic acid, viscosity, RVA

\section{Introduction}

Barley (Hordeum vulgare L.) is a resilient plant, tolerant of a range of conditions, which may have been cultivated since 15000 B.C. (Fast and Caldwell, 2000). Barley is grown as a commercial crop in some hundred countries world-wide and is one of the most important cereal crops in the world. Barley assumes the fourth position in total cereal production in the world after wheat, rice and maize, each of which covers nearly $30 \%$ of the world's total cereal production (Reddy et al., 2014). Barley is usually classified as spring and winter types, two-rowed or sixrowed and hulled or hull-less. Hullless barley requires minimal milling process, owing to the absence of hulls, and remain most of the germ and endosperm which is occasionally lost in the process of pearling or dehulling (Gangopadhyay et al., 2015). 
The use of roller-mills ends up in darker flour with a higher ash content caused by an increased brittleness of the hull and consequently a deteriorated separation of bran and shorts (Klamczynski and Czuchajowska, 1999). Tempering barley before milling process can increase particle size and reduce the proportion of fines particles less than 1.0mm (Hironaka et al., 1992). On the other hand, Quinde et al., (2004) reported that, although, barley had a variety of potential food uses, the dark gray color of the final products negatively affected consumer acceptability, and they mentioned that discoloration potential of barley in food products was dependent on the class and genotype of barley. In addition, Izydorczyk et al., (2003) studied the effect of increasing the moisture content of tempered Canadian hull-less barley before milling from 12.5 to $14.5 \%$; and found strongly improving in flour brightness with a moderate loss of flour yield on a whole un-pearled barley basis; and when the moisture content increased to $16.5 \%$, flour yield decreased without improvement in brightness.

In recent times barley has been mainly used as animal feed or has been processed into beer malt, while only a minor amount $(2 \%)$ of total world production of barley has been used in human food production (Baik and Ullrich, 2008). The reasons that make barley unpopular as human food are: (i) presence of a husk that is difficult to remove, (ii) most of the barley is used up by the malting and brewing industry, (iii) barley lacks the gluten proteins therefore cannot be used in leavened bakery products and (iv) strong taste and gummy mouth feel of whole barley kernels (Sharma and Gujral., 2010). Barley should be used as a human food because it has one of the highest levels (up to $6 \%$ ) of $\beta$ glucan, a water-soluble polysaccharide, nutritionally classified as soluble dietary fiber (Dandey and Bobraszczyk, 2001). Recently, barley flour and whole grain products have been formulated in food research laboratories to increase the diversity of barley food products available and to improve the utilization potential of these healthful grains (Badr et al., 2000). Scientific evidence shows that adding barley to one's diet can provide health benefits of serum cholesterol lowering (Coles et al., 2007), barley $\beta$-glucan controls blood glucose better and lowers glycemic index as well as improve the insulin response (Östman et al., 2007) . In previous investigations of Swanson and Penfield (1988) and Dhingra and Jood (2004) indicated that wheat bread with barley flour added at $15-20 \%$ was acceptable in overall flavor, appearance and texture, but an increase portion of barley flour caused a decrease in loaf volume and, dull brown color and hard crumb texture.

Egypt is one of the largest wheat importing countries, because the yearly local production of wheat covered only about $52-55 \%$ of total requirements for bread making and other bakery products (Othmann and Barghash, 2015). Egypt faces great problem in increasing of population rate and consequently increasing of imported wheat, therefore, we trying 
to decrease the amount of imported wheat using the mixing of other cereals such as barley flour with wheat flour for bread production. The objective of the present work was therefore to study the effect of different moisture contents of tempered hulled and hull-less barley grains prior to milling on extraction rate, color and characteristics of flour.

\section{2-Materials and Methods}

2.1.Materials: Grain samples of hulled barley cultivars Giza 123 and hull-less barley cultivars Giza 130 were purchased from Agricultural Research Center of Giza.

\subsection{Methods:}

2.2.1. Milling: $50 \mathrm{~kg}$ of each hull and hull-less barley grains sample were cleaned thoroughly, and the foreign seeds and materials were removed by hand picking followed by sieving. The barley grains were then conditioned by wetting the grains using different amounts of tap water. The tempering process was completed by mixing and storing the moist grains for 15-24 hours to obtain different moisture contents of tempered grains at 12, 14, 16, and $18 \%$ o prior to milling. Milling was run in a local stone mill. The straight flours thus obtained was sieved through suitable sieves $(350,300$ and $250 \mu \mathrm{m})$ to flour and other milling fractions. The obtained flour samples were cooled immediately and stored in air tight plastic containers at $4{ }^{\circ} \mathrm{C}$ until analysis.

\subsubsection{Analytical Methods}

\subsubsection{1. determination of bar-}

ley flour color: The color of barley flour samples was carried out according to the method described by
Bao et al. (2005) using a Hunter Colorimeter fitted with optical sensor (Momcolor Inc.) on the basis of CIE $\mathrm{L}^{*}, \mathrm{a}^{*}, \mathrm{~b}^{*}$ color space. $L^{*}$ is a measure of the brightness from black (0) to white (100). Parameter $a^{*}$ describes red-green color with positive $a^{*}$ values indicating redness and negative $a^{*}$ values indicating greenness. Parameter $b^{*}$ describes yellowblue color with positive $b^{*}$ values indicating yellowness and negative $b^{*}$ values indicating blueness. The total color difference $(\Delta E)$ was calculated from the Hunter $L, a$ and $b$ values according to Equation: $\Delta E=\left(L^{2}+a^{2}+b^{2}\right)^{0.5}$. The Chroma value indicates color intensity or saturation and it is equal $\left(a^{2}+b^{2}\right)^{0.5}$. Hue angle was calculated as $H^{o}$ and is equal $\tan ^{-1}\left(b^{*} / a^{*}\right)$.

2.2.2.2. Determination of chemical composition:

Moisture, protein, starch, reducing sugars, crude fat, crude fibers and ash contents were determined according to the methods described in the AOAC (1995). Total pentosan content was determined by a colorimetric phloroglucinol method (Douglas, 1981) using xylose as a standard. The total $\beta$-glucan was quantified according to the method reported by McCleary and Glennie (1985) using a ' $\beta$-glucan assay kits (Megazyme International Ireland Ltd., Wicklow, Ireland). For determination of free, bound and total phenolic compounds, the method descript by Abdel-Gawad (1982) was used for liberation and extraction of total phenolic compounds from the samples via alkali hydrolysis followed by extraction the phenolics at $\mathrm{pH} 3.5$ using diethyl acetate, dehy- 
dration with anhydrous sodium sulfate, removing diethyl acetate and finally the residue was dissolved in methanol. Free phenolic compounds were extracted from the samples by methanol only without alkali hydrolysis. Phenolic compounds were determined by Folin-Ciocalteu method spectrophotometrically (Singleton and Rossi, 1965), and as standard gallic acid were used. The results were expressed as milligrams of gallic acid equivalents (GAE) per100 gram of flour sample on dry weight basis. Bound phenolic compounds were calculated by subtract free phenolics from total phenolics. The phytic acid was determined in terms of its phosphorous content, using the method described by Kent-Jones and Amos (1957). The phytic acid (IP6) was calculated from phytate phosphorus from the weight ratio of phosphorus atoms per molecule of IP6 (1:3.52) according to AbdelGawad 2016. The water-soluble protein, starch, pentosan and $\beta$-glucan were determined in water soluble extract of barley flours by mixing $10 \mathrm{~g}$ flour with $100 \mathrm{ml}$ of distilled water; stirred for $15 \mathrm{~min}$ at room temperature $\left(22^{\circ} \mathrm{C} \pm 1\right)$, then centrifuged for $10 \mathrm{~min}$ at $2500 \mathrm{rpm}$. The obtained supernatant was filtered through filter paper Whitman No.1 in a measuring flask $100 \mathrm{ml}$ and finally dilute with distilled water to the mark. Aliquots of extract were used for determination of protein (Lowry et al., 1951), starch (AOAC, 1995), pentosan (Douglas, 1981) and $\beta$-glucan (McCleary and Glennie, 1985).

\subsubsection{Relative viscosity of} water soluble extract: The watersoluble fraction was obtained with- out endogenous enzyme inactivation, using a simple water extraction (flour to distilled water 1:10), with constant starring $(150 \mathrm{rpm})$, at three different temperatures 25,35 and $45^{\circ} \mathrm{C}$ in water bath. The extracts were centrifuged for 10 minutes at $5,000 \mathrm{rpm}$. Following the centrifugation, an aliquot of $5 \mathrm{ml}$ supernatant was removed for the relative viscosity assay by Micro-UBBELOHDE viscometer according to method of Richter et al. (1968). All results were expressed as values relative to that of water.

2.2.2.4 Rapid Visco Analyser: The pasting behaviors of barley flours were evaluated using Rapid Visco-Analyzer (Perten instruments, a Perkin Elmer company) and conducted following the manufacture's instruction and as described by Higley et al. (2003).

\subsubsection{Statistical analysis:} Analysis of variance and significant differences among means were tested by one-way ANOVA using SPSS software (version 16.0 for Windows, SPSS Inc., Chicago, IL). Analysis of Variance (ANOVA) was completed using Duncan's multiple comparison for mean difference testing.

\section{Results and Discussions}

\subsection{Extraction rate of flour:}

It is common knowledge that conditioning moisture has a profound effect on wheat milling product yield and product refinement (Dexter and Martin 2002). Therefore, the effect of different moisture contents of tempered barley grains prior to milling on yield of flour and other milling fractions of hulled and hull-less barley were examined. Fig- 
ure 1 showed the yield of milling fractions of hulled and hull-less barley grains, which milled at different moisture levels $(12 \%, 14 \%, 16 \%$ and $18 \%)$. After milling of barley grains using a local stone mill and sieving of whole flour, hulled barley grains produce four milling fractions: flour, fine bran, coarse bran and hulls whereas, the hull-less barley grains produce the same first three milled products, but without hulls fraction. The most of hulls of hull-less barley grains are removed during washing and tempering treatment of grains. The flour yield of both barley cultivars ranged from 41.83 to $83.10 \%$, and the highest flour extraction rate $(83.10 \%)$ was observed for hull-less barley grains at conditioning moisture of $12 \%$. In previous studies, Izydorczyk et al. (2003) reported that the extraction rate for roller milled barley cultivars ranging from $51.1 \%$ to $63.1 \%$ and Bhatty (1999) found the average of flour extraction rate ranged from $43 \%$ to $60 \%$ for different barley cultivars. It could be seen from Figure 1, that the increase of moisture content of barley grains from 12 to $18 \%$ prior to milling decreased the flour yield from 58.52 to $41.83 \%$ in hulled barley and from 83.10 to $68.32 \%$ in hull-less barley. Generally, the Figure 1 indicated a negative correlation between moisture content of barley grains prior to milling and flour yield. This confirm the fact that when the conditioning moisture increases the husk and outer layers of grains become more moist so that preventing the formation of fine particles during milling. Some previous investigations indicated that the increase in moisture content of tempered hull-less barley from 9 to $16 \%$ caused decreasing in flour yield (Bhatty, 1997) and change in particle size distribution as well as lowering of flour yield (AlSuaidy, 1971).
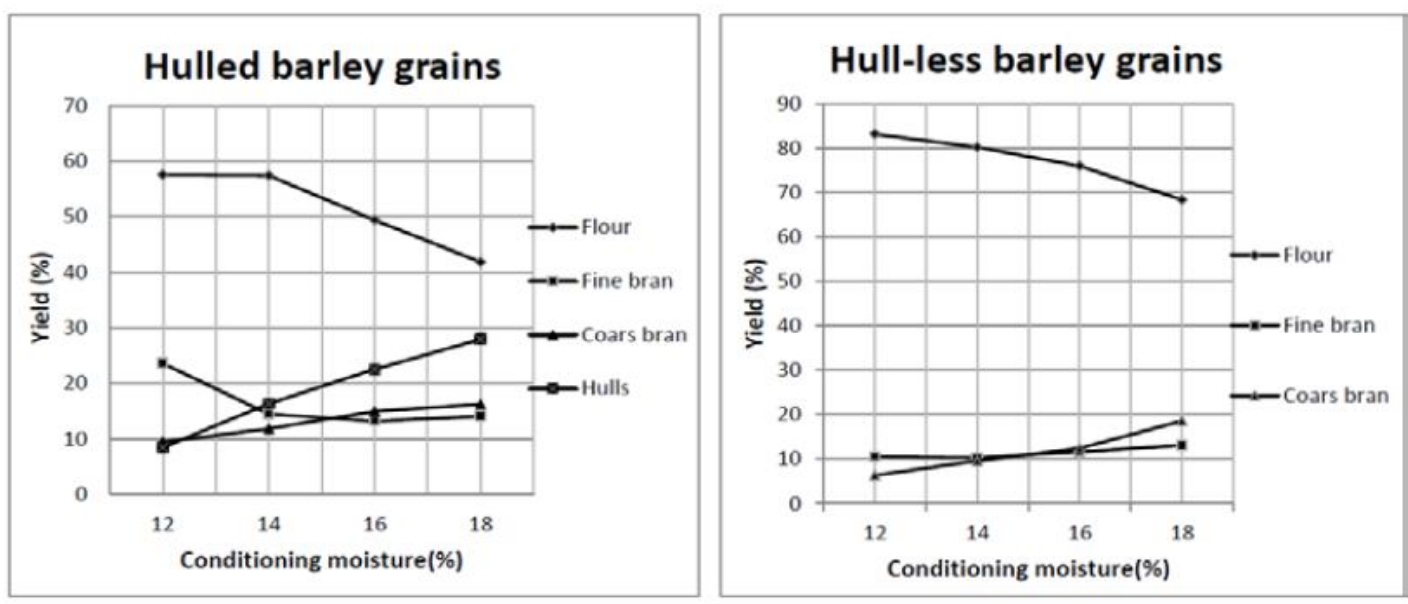

Fig.1: yield of milling fractions of hulled and hull-less barley grains. 


\subsection{Flour color:}

The color of flour is a matter of the greatest importance in the milling industry because it affects the color of the crumb of finished baked product. The color of barley flour was evaluated by CIE Lab color scale $\left(L^{*}, a^{*}\right.$ and $\left.b^{*}\right)$. The $L^{*}$ value indicates the lightness, $0-100$, representing (0) dark to (100) light. The statistical analysis in Table 1 indicated that the $L^{*}$ value of flour was significantly affected by barley cultivars. The flour from hull-less barley had higher $L^{*}$ values (white) than that corresponding flour from hulled barley as a consequence of the hull and pericarp particles present in the flour of the latter variety. Barley flour color varies not only with different cultivars but also within the same cultivars grown in different seasons and in different growth locations (Bhatty, 1993). The color of different flours from each cultivars (Table 1) was dependent on the moisture content of grains prior to milling. The low moisture content of conditioning $(12 \%)$ resulted in low $L^{*}$ value (dark color) for flour from both cultivars. The statistical analysis of the data in Table 1 indicated significant higher $L^{*}$ values for flours from hull-less barley milled at $14 \%, 16 \%$ and $18 \%$ moisture prior to milling than that of corresponding flours from hulled barley milled at the same tempering moisture content. The $L^{*}$ values which indicated the brightness of color were increased as the conditioning moisture of hull-less barley increased and the flour of this variety which milled at high moisture (18\%) showed significantly the highest $L^{*}$ value. The re- sults of Table 1 showed improving in color brightness of flours from hulled variety milled at 14 and $16 \%$ moisture content before milling but no significant differences among themselves. The results of our study are agreement of that reported by Izydorczyk et al., 2003; they found that increasing conditioning moisture from 12.5 to $14.5 \%$ strongly improved flour brightness with only a moderate loss of flour yield and as the moisture content was increased to $16.5 \%$, flour yield declined without a compensating improvement in brightness. The $\mathrm{a}^{*}$ value which gives the degree of the red-green color, with a higher positive $a^{*}$ value indicating more redness. In this study, the changes in redness or a* values of flours were high significant as affected by barley cultivars and ranged from 0.14 to 0.4 , with variable changes between tempering levels. On the other hand, there was a trend to increase in $a^{*}$ values of flours milled from hulled barley grains and decrease in these values for the flours of hull-less barley with increasing the conditioning moisture levels. Actually, flour color in barley is influenced by anthocyanin pigments (purple, blue, or dark) (Bhatty, 1993). The $b^{*}$ value indicates the degree of yellow-blue color, with higher positive $b^{*}$ value indicating more yellow. The $b^{*}$ value of flour was affected significantly with barley cultivars. The $b^{*}$ value ranged from 5.68 to 9.73 . The highest $b^{*}$ value was observed for flour from $18 \%$ conditioning treatment of hullless barley grains and the lowest for flour from $12 \%$ conditioning treatment of hulled barley. Sharma and 
Gujral (2010) studied the color properties of eight commonly grown Indian hulled barley cultivars and reported similar results for $L^{*}, b^{*}$ and $\mathrm{a}^{*}$ color values. Although particle size differences influenced results, the differences in the CIELAB color space parameters were related to flour ash contents and flour yellow pigment contents. $L^{*}$ was correlated with flour ash content (Oliver et al., 1993). The total color difference $(\Delta E)$ of flours was significantly affected by barley cultivars. There was an increase in $\Delta E$ value with increment of moisture content of tempered barley grains. The highest $(\Delta E)$ value was observed for $18 \%$ conditioning moisture while $12 \%$ conditioning treatment had the lowest value in both barley cultivars. The statistical analysis in Table 1 indicated that the chroma values were significantly affected with barley cultivars. The term Hue is defined as an attribute of visual perception according to which an area appears to be similar to one of the colors red, yellow, green, and blue, or to a combination of adjacent pairs of colors considered in a closed ring (C.I.E, 1987). There was a relationship between the values of $a *$ and $b *$ and the range of hue angles were $0-90^{\circ}$ (Choudhury, 2014).

Table 1: Effect of moisture content of tempered barley grains prior to milling on the color of flour.

\begin{tabular}{|c|c|c|c|c|c|c|c|}
\hline Samples & $\begin{array}{c}\text { Moisture content } \\
\text { of barley grains } \\
\text { prior to milling } \\
(\%)\end{array}$ & $L^{*}$ & $a^{*}$ & $b^{*}$ & $\Delta E$ & Chroma & Hue \\
\hline \multirow{4}{*}{$\begin{array}{c}\text { Flours from Giza } \\
123 \\
\text { (hulled barley) }\end{array}$} & 12 & $73.44 f$ & $0.14 d$ & $5.68 \mathrm{~h}$ & $13.38 \mathrm{~h}$ & $5.68 \mathrm{~h}$ & $88.58 \mathrm{a}$ \\
\hline & 14 & $77.53 c$ & $0.18 \mathrm{~cd}$ & $6.09 \mathrm{~g}$ & $13.86 \mathrm{~g}$ & $6.09 \mathrm{~g}$ & $88.31 c$ \\
\hline & 16 & $77.76 \mathrm{c}$ & $0.16 \mathrm{bcd}$ & $6.38 \mathrm{f}$ & $14.01 \mathrm{f}$ & $6.38 \mathrm{f}$ & $88.56 \mathrm{a}$ \\
\hline & 18 & $77.00 \mathrm{~d}$ & $0.40 \mathrm{a}$ & $7.22 \mathrm{~d}$ & $14.36 \mathrm{e}$ & $7.23 d$ & $86.83 \mathrm{~g}$ \\
\hline \multirow{4}{*}{$\begin{array}{c}\text { Flours from Giza } \\
130 \\
\text { (hull-less barley) }\end{array}$} & 12 & $76.48 \mathrm{e}$ & $0.38 \mathrm{~b}$ & $7.61 \mathrm{c}$ & $14.53 d$ & $7.62 \mathrm{c}$ & $87.14 \mathrm{e}$ \\
\hline & 14 & $87.96 \mathrm{~b}$ & $0.36 \mathrm{bc}$ & $7.75 \mathrm{~b}$ & $15.36 \mathrm{~b}$ & $7.76 \mathrm{~b}$ & $87.34 d$ \\
\hline & 16 & $88.06 b$ & $0.37 \mathrm{~b}$ & $7.18 \mathrm{e}$ & $15.09 \mathrm{c}$ & $7.19 \mathrm{e}$ & $87.05 f$ \\
\hline & 18 & $89.47 a$ & $0.26 \mathrm{bcd}$ & $9.73 a$ & $16.54 a$ & $9.73 a$ & $88.47 \mathrm{~b}$ \\
\hline
\end{tabular}

Each value is the mean of triplicate determinations. Different letters means significant differences at $(p<0.05)$, whereas values with the same letter means no significant differences.

\subsection{Chemical composition:}

The changes in gross chemical composition of flours obtained from tempered barley grains with different moisture contents prior to milling are shown in Table 2. The moisture contents of flours obtained from hulled and hull-less barley were increased significantly with increasing the moisture contents of tempered grains. The moisture content of a flour after milling are ordinarily dependent on the moisture content of tempered grains and the degree of heating produced during milling (Srinivasan and Smith, 2012). Protein, crude fat, pentosan, $\beta$-glucan, crude fiber and ash contents of flours from both cultivars were decreased significantly with increment the moisture content of grains prior to milling. The decrease of these components is related to lowering the flour extraction rate because most of them are localized in outer layers of grains than in endosperm. In addi- 
tion, the increasing of moisture contents of tempered grains prevented the formation of fine particles of grain outer layers during milling and therefore pass not through the sieves during flour production (Kent-Jones and Amos, 1967). The increase of moisture content of barley grains from 12 to $18 \%$ prior to milling decreased the total $\beta$-glucan content from 3.84 to $2.37 \%$ in hulled barley flour and from 4.20 to $3.37 \%$ in hullless barley flour. This confirms the fact that when the conditioning moisture increases, the husk and outer layers of grains become moist, so that decreasing the flour contamination with fine particles which containing higher amount of $\beta$-glucan. In this concept Bhatty (1993) showed that amount of total beta glucan content of flour, bran and shorts of hull-less barley was 4.3, 6.3 and $8.4 \%$; respectively on free moisture basis. Besides, Zheng et al., (2011) reported that the flour of six hull-less barley cultivars had the lowest concentration of $\beta$-glucan, which was derived from the endosperm cell walls.

Starch, reducing sugars and free phenolics of flours of both cultivars were increased with increment of conditioning moisture content. The increasing of starch is related to low flour extraction rate because the starch localized mainly in endosperm cells, whereas the increase in reducing sugars and free phenolics is as result of enzymes activation at high moisture content during conditioning process. Kleinwächter et al. (2014) reported variable activities of the enzymes $\alpha$-amylase, $\beta$-amylase and $\beta$ glucanase in the different steeped barley. The increase in free phenolics and decrease in bound and total phenolic content in both barley cultivars (Table 2) may be attributed to the bound phenolics becoming free by the action of enhanced hydrolytic enzyme activity (Mailard et al. 1996). The phenolic compounds are mainly concentrated in cell walls of the grain outer layer mostly esterified to the arabinose side groups of arabinoxylans (Mailared and Berest, 1995). The phytate phosphorus and phytic acid content varied significantly among barley cultivars. The hulled barley flours contain higher phytate than hull-less barley flour because the hulls and pericarp in hull variety contain higher phytate than the endosperm. The phytate content decreased in all tested flours as the tempered moisture of grains prior milling increased which may be due to the lowering of flour extraction rate and/or to enhancing activity of enzyme phytase during conditioning process. 


\begin{tabular}{|c|c|c|c|c|c|c|c|c|c|c|c|c|c|c|c|}
\hline \multirow[t]{3}{*}{ Samples } & \multirow{3}{*}{\begin{tabular}{|c|} 
Moisture \\
content of \\
barley \\
grains \\
prior to \\
milling \\
$(\%)$
\end{tabular}} & \multirow{3}{*}{$\begin{array}{c}\text { Moisture } \\
(\%)\end{array}$} & \multicolumn{13}{|c|}{ Chemical composition of barley flours (on dry weight basis) } \\
\hline & & & \multirow[t]{2}{*}{$\begin{array}{c}\text { protein }^{*} \\
(\%)\end{array}$} & \multirow[t]{2}{*}{$\begin{array}{l}\text { fat }^{*} \\
(\%)\end{array}$} & \multirow[t]{2}{*}{$\begin{array}{l}\text { starch* }^{*} \\
(\%)\end{array}$} & \multirow[t]{2}{*}{$\begin{array}{c}\text { Pentosan } \\
(\%)\end{array}$} & \multirow[t]{2}{*}{$\begin{array}{c}\beta \text {-Glucan } \\
(\%)\end{array}$} & \multirow{2}{*}{$\begin{array}{c}\text { Reducing } \\
\text { sugars* } \\
(\%)\end{array}$} & \multirow{2}{*}{$\begin{array}{c}\begin{array}{c}\text { Crude } \\
\text { fiber* } \\
(\%)\end{array}\end{array}$} & \multirow[t]{2}{*}{$\begin{array}{l}\text { Ash }^{*} \\
(\%)\end{array}$} & \multicolumn{3}{|c|}{$\begin{array}{l}\text { phenolic compounds } \\
\text { (mg GAE } / 100 \mathrm{~g} \text { flour) }\end{array}$} & \multirow{2}{*}{$\begin{array}{c}\text { phytic acid } \\
\text { phosphorus } \\
\text { (mg/100g flour) }\end{array}$} & \multirow{2}{*}{$\begin{array}{l}\text { phytic acid } \\
\text { (mg/100g } \\
\text { flour) }\end{array}$} \\
\hline & & & & & & & & & & & Free & Bound & Total & & \\
\hline \multirow{4}{*}{$\begin{array}{l}\text { Flours } \\
\text { from } \\
\text { Giza123 } \\
\text { (hulled } \\
\text { barley) }\end{array}$} & 12 & $10.55 \mathrm{~h}$ & $11.03 \mathrm{c}$ & $2.37 \mathrm{~b}$ & $70.16 \mathrm{~h}$ & 4.16a & $3.84 \mathrm{~b}$ & $0.600 \mathrm{f}$ & $2.49 \mathrm{a}$ & $1.76 \mathrm{a}$ & $66.10 \mathrm{~h}$ & $162.77 \mathrm{a}$ & $228.87 \mathrm{c}$ & $158.45 \mathrm{a}$ & 562.17a \\
\hline & 14 & $11.73 \mathrm{f}$ & $10.95 \mathrm{~d}$ & $1.97 \mathrm{~d}$ & $70.46 \mathrm{~g}$ & $4.12 \mathrm{~b}$ & $3.63 \mathrm{~d}$ & $0.637 \mathrm{e}$ & $2.42 \mathrm{~b}$ & $1.74 \mathrm{~b}$ & $87.38 \mathrm{~g}$ & $125.75 \mathrm{~d}$ & $213.13 \mathrm{e}$ & $158.09 \mathrm{~b}$ & $560.92 \mathrm{~b}$ \\
\hline & 16 & $12.10 \mathrm{~d}$ & $10.39 \mathrm{e}$ & $1.87 \mathrm{e}$ & $71.20 \mathrm{f}$ & $3.81 \mathrm{c}$ & $3.62 \mathrm{e}$ & $0.705 \mathrm{~d}$ & $1.85 \mathrm{e}$ & $1.69 \mathrm{c}$ & $103.73 \mathrm{f}$ & $74.56 \mathrm{e}$ & $178.29 \mathrm{~g}$ & $94.59 \mathrm{f}$ & $335.63 \mathrm{f}$ \\
\hline & 18 & $12.49 \mathrm{c}$ & $9.81 \mathrm{f}$ & $1.67 \mathrm{~g}$ & $72.06 \mathrm{e}$ & $2.62 \mathrm{~d}$ & $2.37 \mathrm{~h}$ & $0.770 \mathrm{c}$ & $1.84 \mathrm{e}$ & $1.67 \mathrm{~d}$ & $107.41 \mathrm{e}$ & $59.73 \mathrm{~g}$ & 167.14h & $93.60 \mathrm{~g}$ & $332.08 \mathrm{~g}$ \\
\hline \multirow{4}{*}{$\begin{array}{l}\text { Flours } \\
\text { from } \\
\text { Giza130 } \\
\text { (hull-less } \\
\text { barley) }\end{array}$} & 12 & $11.37 \mathrm{~g}$ & 11.67a & 2.41a & $77.08 \mathrm{~d}$ & $2.58 \mathrm{e}$ & $4.20 \mathrm{a}$ & $0.744 \mathrm{~cd}$ & $2.20 \mathrm{~d}$ & $1.41 \mathrm{e}$ & $112.21 \mathrm{~d}$ & $137.18 \mathrm{~b}$ & $249.39 \mathrm{a}$ & $147.55 \mathrm{c}$ & $523.53 \mathrm{c}$ \\
\hline & 14 & $11.98 \mathrm{e}$ & $11.29 \mathrm{~b}$ & $2.06 \mathrm{c}$ & $77.92 \mathrm{c}$ & $2.54 \mathrm{f}$ & $3.78 \mathrm{c}$ & $0.744 \mathrm{~cd}$ & $2.28 \mathrm{c}$ & $1.34 \mathrm{f}$ & $116.76 \mathrm{c}$ & $128.63 \mathrm{c}$ & $245.39 \mathrm{~b}$ & $124.09 \mathrm{~d}$ & $440.30 \mathrm{~d}$ \\
\hline & 16 & $12.96 \mathrm{~b}$ & $11.03 \mathrm{c}$ & $1.89 \mathrm{e}$ & $78.87 \mathrm{~b}$ & $2.42 \mathrm{~g}$ & $3.56 \mathrm{f}$ & $1.04 \mathrm{~b}$ & $1.86 \mathrm{e}$ & $1.32 \mathrm{~g}$ & $151.74 \mathrm{~b}$ & $70.13 \mathrm{f}$ & $221.87 \mathrm{~d}$ & $114.28 \mathrm{e}$ & $405.46 \mathrm{e}$ \\
\hline & 18 & $13.04 \mathrm{a}$ & $10.89 \mathrm{~d}$ & $1.72 \mathrm{f}$ & $79.39 \mathrm{a}$ & $2.09 \mathrm{~h}$ & $3.37 \mathrm{~g}$ & $1.11 \mathrm{a}$ & $1.65 \mathrm{f}$ & $1.29 \mathrm{~h}$ & $175.38 \mathrm{a}$ & $34.3 \mathrm{lh}$ & $209.69 \mathrm{f}$ & $78.10 \mathrm{~h}$ & 277.12h \\
\hline
\end{tabular}

\section{nents:}

\subsection{Solubility of flour compo-}

The values of protein solubility in distilled water of different barley flours ranged from 9.94 to $13.05 \%$ (Table 3). There was small increase in protein solibility of flours with increasing the conditioning moisture before milling. Soluble starch content of barley flours increased significantly in both barley varieties by increase of conditioning moisture of the grains before milling but the increment was higher in hulled barley flour than that in hull-less barley flour. The increase in soluble starch content may be due to the degradation of starch by amylases, which activated during tempering of barley grains, into low molecular weight fragments (Hug-Iten et al., 2003). The soluble starch extracted at room temperature $\left(22^{\circ} \mathrm{C} \pm 1\right)$ from flours of two barley cultivars and determined as a percentage of total flour starch ranged from 0.25 to $3.25 \%$ (Table 3 ). These results are similar to that reported for wheat $(0.9-1.67 \%)$ by Kulp and Lorenz (1981) and for three barley cultivars $(0.9-2.1 \%)$ by Šbarić et al., (2011). In addition, it could be seen from Table 3 that the content of soluble pentosans in barley flours ranged from 0.16 to $0.46 \%$; and there was an increase in water-soluble pentosan contents with increasing the moisture content of tempered grains. This increase may be due to increase the activity of xylanases by increment of conditioning moisture. The soluble pentosan as a percentage of total flour pentosan was increased from $5.77 \%$ to $17.56 \%$ in hulled barley flours and from $6.14 \%$ to $8.67 \%$ in hull-less barley flours as moisture tempering increase from $12 \%$ to $18 \%$; respectively. Andersson et al., (2003) reported that the arabinoxylan contents in straight-run white flours of four hull-less barley samples (conditioned to $14.3 \%$ moisture) were $1.2-1.5 \%$, of which $\approx 17 \%$ was waterextractable. The solubility of pentosan in hull-less barley flours were lower than hulled barley flours (Table 3). It is known that the husk of barley contains high contents of pentosan than the endosperm. On contrary Holtekjølen et al., (2006) found that hull-less varieties having a significantly higher content of soluble arabinoxylan than the hulled samples. 
Table 3: Effect of moisture content of tempered barley grains prior to milling on the solubility of flour components (on dry weight basis).

\begin{tabular}{|c|c|c|c|c|c|c|c|c|c|}
\hline Samples & $\begin{array}{l}\text { Moisture } \\
\text { content of } \\
\text { barley grains } \\
\text { prior to } \\
\text { milling ( } \%)\end{array}$ & $\begin{array}{c}\text { Soluble } \\
\text { protein } \\
\text { (g/100g flour) }\end{array}$ & $\begin{array}{c}\text { Soluble } \\
\text { protein as } \% \\
\text { of total flour } \\
\text { protein }\end{array}$ & $\begin{array}{l}\text { Soluble } \\
\text { starch } \\
(\mathrm{g} / 100 \mathrm{~g} \text { flour })\end{array}$ & $\begin{array}{l}\text { Soluble } \\
\text { starch as \% } \\
\text { of total flour } \\
\text { starch }\end{array}$ & $\begin{array}{c}\text { Soluble } \\
\text { pentosan } \\
(\mathrm{g} / 100 \mathrm{~g} \text { flour })\end{array}$ & $\begin{array}{c}\text { Soluble } \\
\text { pentosan as } \\
\% \text { of total } \\
\text { flour } \\
\text { pentosan }\end{array}$ & $\begin{array}{c}\text { Soluble } \beta \text { - } \\
\text { glucan } \\
\text { (g/100g flour) }\end{array}$ & $\begin{array}{c}\text { Soluble } \beta \text { - } \\
\text { glucan as } \% \\
\text { of total flour } \\
\beta \text {-glucan }\end{array}$ \\
\hline \multirow{4}{*}{$\begin{array}{l}\text { Flours from } \\
\text { Giza123 } \\
\text { (hulled barley) }\end{array}$} & 12 & $1.23 \mathrm{~b}$ & $11.15 \mathrm{e}$ & $1.46 \mathrm{~d}$ & $2.08 \mathrm{~d}$ & $0.24 \mathrm{~d}$ & $5.77 \mathrm{~g}$ & $1.53 c$ & $39.84 \mathrm{e}$ \\
\hline & 14 & $1.22 \mathrm{~b}$ & $11.14 \mathrm{e}$ & $1.98 \mathrm{c}$ & $2.81 \mathrm{c}$ & $0.30 \mathrm{c}$ & $7.28 \mathrm{~d}$ & $1.67 \mathrm{~b}$ & $46.00 \mathrm{c}$ \\
\hline & 16 & $1.26 \mathrm{a}$ & $12.13 \mathrm{~b}$ & $2.05 \mathrm{~b}$ & $2.88 \mathrm{~b}$ & $0.31 \mathrm{~b}$ & $8.14 c$ & $1.71 \mathrm{~b}$ & $47.24 b$ \\
\hline & 18 & $1.28 \mathrm{a}$ & $13.05 a$ & $2.34 \mathrm{a}$ & $3.25 a$ & $0.46 a$ & $17.56 \mathrm{a}$ & $1.94 \mathrm{a}$ & $81.85 a$ \\
\hline \multirow{4}{*}{$\begin{array}{l}\text { Flours from } \\
\text { Giza130 } \\
\text { (hull-lessbarley) }\end{array}$} & 12 & $1.16 \mathrm{c}$ & $9.94 \mathrm{~g}$ & $0.19 \mathrm{~h}$ & $0.25 \mathrm{~h}$ & $0.16 \mathrm{~g}$ & $6.20 \mathrm{f}$ & $0.67 \mathrm{f}$ & $15.95 \mathrm{~h}$ \\
\hline & 14 & $1.18 \mathrm{c}$ & $10.49 \mathrm{f}$ & $0.25 \mathrm{~g}$ & $0.32 \mathrm{~g}$ & $0.16 \mathrm{~g}$ & $6.29 \mathrm{f}$ & $1.36 \mathrm{e}$ & $35.97 \mathrm{~g}$ \\
\hline & 16 & $1.26 \mathrm{a}$ & $11.42 \mathrm{~d}$ & $0.3 \mathrm{lf}$ & $0.39 \mathrm{f}$ & $0.17 \mathrm{f}$ & $7.02 \mathrm{e}$ & $1.40 \mathrm{de}$ & $39.33 \mathrm{f}$ \\
\hline & 18 & $1.26 \mathrm{a}$ & $11.57 \mathrm{c}$ & $0.38 \mathrm{e}$ & $0.48 \mathrm{e}$ & $0.18 \mathrm{e}$ & $8.6 \mathrm{lb}$ & $1.44 \mathrm{~d}$ & $42.73 \mathrm{~d}$ \\
\hline
\end{tabular}

The soluble $\beta$-glucan content exhibited significantly increasing in flours of both barley varieties as the moisture content of tempering grains before milling increased (Table 3). Such increase may be due to hydration and solubilization of more betaglucan molecules from the cell wall matrix when the moisture content of tempered grains enhanced. In this study, the soluble $\beta$-glucan in barley flours ranged from 1.53 to $1.94 \%$ in hulled barley and 0.67 to $1.44 \%$ in hull-less barley. Likewise AnkerNilssen et al. (2008) reported that the water-soluble $\beta$-glucan contents for eight different cultivars and five different growth temperatures ranged from $0.6 \%$ to $3.3 \%$ (on dry weight). The flours from hulled barley showed significantly higher $\beta$-glucan solubility (soluble $\beta$-glucan as a percent of total flour $\beta$-glucan) than that of flours from hull-less barley. It increased from $39.84 \%$ to $81.85 \%$ and from $15.95 \%$ to $42.73 \%$ in flours of hulled and hull-less barley verities when the tempered moisture of grains raised from $12 \%$ to $18 \%$; respectively. Izydorczyk et al., (2000) showed that extractability of soluble $\beta$-glucan ranged between $20.6 \%$ and $52.5 \%$. Benito-Román et al., (2011) reported that the solubility represents the maximum amount of $\beta$-glucan that can be dissolved in water to form a homogenous solution under controlled conditions of temperature, pressure and molecular weight of the polymer. Generally, the highest solubility values were achieved with the lowest molecular weight of $\beta$ glucans. The higher solubility of $\beta$ glucan and pentosan of hulled barley flours than that observed for hull-less barley flours (Table 3 ) is the reason for the higher relative viscosity of flour water extracts of the former than that of the latter (Fig.2). The relative viscosity of flour water extract determined at different temperatures $\left(25,35\right.$ and $\left.45^{\circ} \mathrm{C}\right)$ indicated variations in decreasing of viscosity as the temperature assay increased. The relative viscosity values were increasingly as the conditioning moisture of grains prior milling raised (Fig.2). Soluble fibers such as mixed-linked $\beta$-glucans in barley (Coles et al., 2007) and arabinoxylans in rye (Wang et al., 2016) or wheat (Skendi and Biliaderis 2016) interfere with the absorption of nutrients, particularly fats, due to the increased viscosity of the intestinal contents. Correspondingly, these fibers lower blood cholesterol (Östman et al., 2007). The reduced fat absorption and blood cholesterol content is probably partly caused by binding or trapping of bile salts in the gut due to high viscosity (Moun- 
dras et al., 1997), and/or a reduced emulsification and lipolysis of the fat (Pasquier et al., 1996). In addition, it has been shown that diets with a high viscosity may increase the microbial activity in the digestive tract (Choct et al., 1996). An increased microbial activity may deconjugate bile salts and alter gut health.
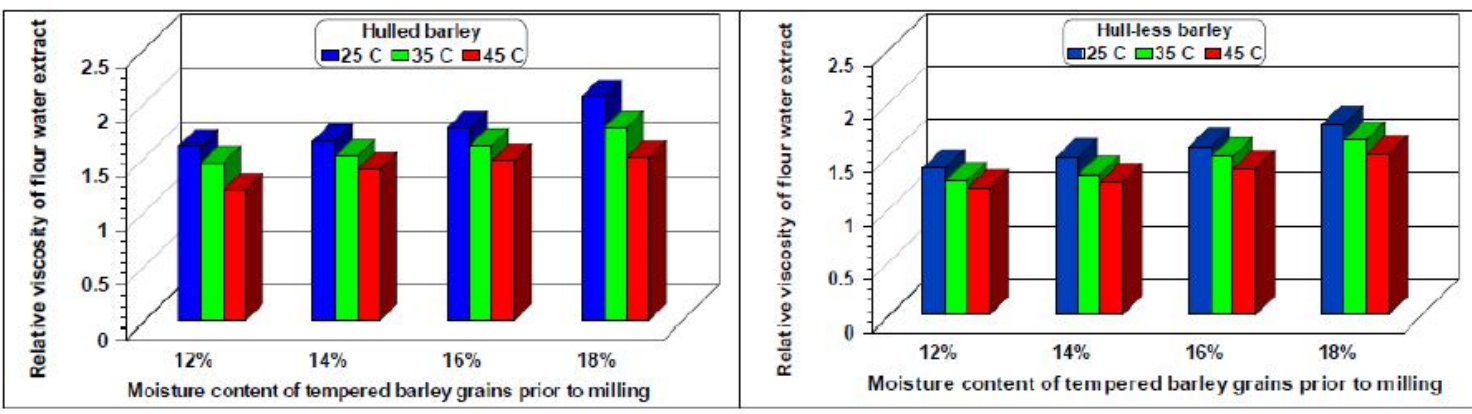

Fig.2: Relative viscosity at different temperatures of flour water extract from hulled and hull-less barley grains tempered at different moisture content prior to milling.

\subsection{Starch characteristics:}

Table (4) illustrated the Rapid Visco Analyser (RVA) measurements for the barley flours obtained from grains milled at different conditioning moisture. The values of barley flours for pasting temperature, time to gelatinization, time to peak, peak viscosity, trough viscosity and final viscosity were decreased as the moisture content of barley grains prior milling was increased. The pasting temperature of flours from hulled and hull-less barley ranged from 75.0 to $84.75^{\circ} \mathrm{C}$. Sharma and Gujral (2010) reported that pasting temperature for eight commonly grown Indian hulled barley cultivars ranged from 81.13 to $85.50^{\circ} \mathrm{C}$ and Eriksson (2012) studied different barley varieties and he found that pasting temperature ranged from $65^{\circ} \mathrm{C}$ to $93^{\circ} \mathrm{C}$. The decrease of time to gelatinization (Table 4) may be due to binding the phosphorus released from degradation of phytic acid as phosphate monoesters with amylose. Ormerod et al. (2002) reported that the higher amylase and divalent cation of starch are consistent with a more raped swelling and gelatinization. Higley et al. (2003) found a negative correlation between the time to gelatinization and the high contents of amylase, phosphorus, calcium and magnesium of starch. Besides, Copeland et al., (2009) showed that the peak time and peak viscosity can be associated with the water absorption capacity. The decrease which happened in peak viscosity after conditioning treatment of both barley cultivars grains to high moisture content may be due to the increase of alpha amylase activity, Preedy et al. (2011) reported that high peak viscosity reflect weak alpha-amylase activity. Tang and Copeland (2007) reported that the content and rate of amylose leaching, resulting in a higher pasting temperature and lower peak viscosity. Trough viscosity is measured at the minimum point following peak viscosity. Breakdown viscosity is the difference between peak and trough viscosity. In this work, the hull-less 
barley flours tended to have lower trough viscosity than the hulled flours. Similar results were reported by (Gray et al., 2010).

In terms of setback parameter, cooling causes the re-association of starch molecules which results in gel structure formation and an increase in final viscosity due to retrogradation. The difference between the final viscosity and the trough viscosity is the setback viscosity. A low setback value is indicative of low retrogradation. Table (4) illustrated that there was a trend to decrease in the total setback with the increase in conditioning moisture. Moreover, the conditioning treatment $18 \%$ of hullless barley had the lowest setback $(570 \mathrm{cP})$ and final viscosities $(802 \mathrm{cP})$. This could suggest that breads containing barley flours obtained from moist grains to $18 \%$ moisture before milling would not stale rapidly than breads containing barley flours obtained from dry milling. Likewise, Gray et al., (2010) reported that hull-less cultivar had significantly lower setback and final viscosities than the other cultivars they studied.

Table 4: Effect of the moisture content of tempered barley grains on the starch characteristics of obtained flour (on base of $14 \%$ moisture)

\begin{tabular}{|c|c|c|c|c|c|c|c|c|c|}
\hline \multirow[b]{2}{*}{ Samples } & \multirow{2}{*}{$\begin{array}{c}\text { moisture } \\
\text { content of } \\
\text { barley grains } \\
\text { prior to } \\
\text { milling } \\
(\%)\end{array}$} & \multicolumn{8}{|c|}{ Rapid Visco Analyser (RVA) characteristics } \\
\hline & & $\begin{array}{l}\text { Pasting } \\
\text { temperature } \\
\text { (C) }\end{array}$ & $\begin{array}{c}\text { Time to } \\
\text { gelatinization } \\
\text { (min) }\end{array}$ & $\begin{array}{l}\text { Time } \\
\text { to } \\
\text { Peak } \\
\text { (min) }\end{array}$ & $\begin{array}{c}\text { Peak } \\
\text { viscosity } \\
\text { (Pa. s) }\end{array}$ & $\begin{array}{c}\text { Breakdown } \\
\text { (Peak- } \\
\text { Trough) } \\
\text { (Pa. s) }\end{array}$ & $\begin{array}{l}\text { Trough } \\
\text { Viscosity } \\
\text { (Pa. s) }\end{array}$ & $\begin{array}{c}\text { Total } \\
\text { setback } \\
\text { (Pa. s) }\end{array}$ & $\begin{array}{l}\text { Final } \\
\text { viscosity } \\
\text { (Pa. s) }\end{array}$ \\
\hline \multirow{4}{*}{$\begin{array}{l}\text { Flours } \\
\text { from } \\
\text { Giza123 } \\
\text { (Hulled } \\
\text { barley) }\end{array}$} & 12 & 84.75 & 3.9 & 6.53 & 3.299 & 1.378 & 1.921 & 1.415 & 3.336 \\
\hline & 14 & 83.9 & 3.8 & 6.33 & 2.745 & 1.205 & 1.540 & 1.303 & 2.843 \\
\hline & 16 & 83.2 & 3.75 & 6.27 & 1.984 & 0.993 & 0.991 & 0.998 & 1.989 \\
\hline & 18 & 81.45 & 3.65 & 5.93 & 1.969 & 1.161 & 0.808 & 1.094 & 1.902 \\
\hline \multirow{4}{*}{$\begin{array}{l}\text { Flours } \\
\text { from } \\
\text { Giza130 } \\
\text { (Hull-less } \\
\text { barley) } \\
\end{array}$} & 12 & 84 & 3.9 & 6.33 & 2.818 & 1.119 & 1.699 & 1.257 & 2.956 \\
\hline & 14 & 81.4 & 3.55 & 5.93 & 2.073 & 1.195 & 0.878 & 1.090 & 1.968 \\
\hline & 16 & 75.0 & 3.3 & 5.93 & 2.048 & 1.250 & 0.798 & 1.198 & 1.996 \\
\hline & 18 & 75.0 & 3.15 & 5.07 & 1.235 & 1.003 & 0.232 & 0.570 & 0.802 \\
\hline
\end{tabular}

\section{Conclusion}

The hulled and hull-less barley grains were conditioned at different moisture content prior milling. The increasing of tempering moisture prior milling decreased the flour extraction rate and improved flour color (become white) with increment the solubility of pentosan and $\beta$ glucan.

\section{Reference}

A.O.A.C. (1995). Official Methods of Analysis of the Association of Official Analytical Chemists, $14^{\text {th }}$ ed., Washington, DC.
Abdel-Gawad, A.S. (1982). Isolierng and charakterisierung von pentosanfraktionen aus verschiedenen weizen sorten. Ph.D. Dissertation Natural Science TU. Berlin, D 83 No.132/FB13. (In German).

Abdel-Gawad, A.S. (2016). Determination of diffrent inositol phosphate forms in raw, soaked and germinating legumes by anion-exchange chromatography. The Pharmaceutical and Chemical Journal, 3(1): 183-191

Al-Suaidy, M. A. (1971). Investigation on the effect of physical and biochemical pre-milling treatments 
on milling and baking properties of hard red winter wheat. Kansas State University, Manhattan, Kansas. Ph.D.

Andersson, A.A.M.; Armo E.; Grangeon, E.; Fredriksson, H.; Andersson, R. and Aman, P. (2003). Milling performance of north European hull-less barleys and characterization of resultant mill-streams. Cereal Chemistry, 80: 667-673.

Anker-Nilssen, K.; Sahlstrøm, S.; Knutsen, S.H.; Holtekjølen, A.K. and Uhlen, A.K. (2008). Influence of growth temperature on content, viscosity and relative molecular weight of water-soluble $\beta$-glucans in barley (Hordeum vulgare L.). Journal of Cereal Science, 48: 670-677.

Badr, A.; Muller, K.; Schafer-pregi, EI Rabey H.; Effgen, S.; Ibrahim, H.H.; Pozzi, C.; Rohde, W.; and Solomini, F. (2000). On the origine and demonstration history of barley. Molecular Biology Evolution Journal, 17(4):499-510.

Baik, B.K. and Ullrich, S.E. (2008). Barley for food: characteristics, improvement, and renewed interest. Critical review. Journal of Cereal Science, 30:1-10.

Bao, J.S.; Cai, Y.; Sun, M.; Wang, G.Y. and Corke, H. (2005). Anthocyanins, flavonols, and free radical scavenging activity of Chinese bayberry (Myrica rubra) extracts and their color properties and stability. Journal of Agricultural and Food Chemistry, 53, 2327-2332.

Benito-Román, O.; Alonso, E. and Lucas, S. (2011). Optimization of the $\beta$-glucan extraction conditions from different waxy barley cultivars. Journal of Cereal Science, 53:271-276
Bhatty, R. S. (1999). $\beta$-Glucan and flour yield of hull-less barley. Cereal Chemistry, 76:314-315.

Bhatty, R.S. (1993). Physicochemical properties of roller-milled barley bran and flour. Cereal Chemistry, 70(4):397-402.

Bhatty, R.S. (1997). Milling of regular and waxy starch hull less barley for the production of bran and flour. Cereal Chemistry, 76:314315.

Choct, M.; Hughes, R.J.; Wang, J.; Bedford, M.R.; Morgan, A.J. and Annison, G. (1996). Increased small intestinal fermentation is partly responsible for the anti-nutritive activity of non-starch polysaccharides in chickens. Breeding Poultry. Science, 37: 609-621.

Choudhury, A. K. R. (2014). Principles of Colour Appearance and Measurement, Volume 1: Object appearance, colour perception, and instrumental measurement. Woodhead Publishing Limited in Association with the Textile Institute.

Commission Internationale de I'Eclairage (CIE). (1987). Guide to the Properties and Uses of Retrorefrectors at Night, CIE Publication 72, Venna: CIE.

Coles, G.D.; Roberts, S.J.; Butler, R.C.; Morrell, M.K. and Rowarth, J.S. (2007). The role of beta-glucan in barley. In: Salovaara, H. Gates, and F. Tenkanen, M. editors. Dietary Fiber Components and Functions. Wageningen: Academic Publishers, pp.65-74.

Copeland, L.; Blazek, J.; Salman, H. and Tang, M.C. (2009). Form and functionality of starch. Food $\mathrm{Hy}$ drocolloids, 23(6): 1527-1534.

Dandey, D. and Bobraszczyk, B.J. (2001). Cereals and Cereal Products Chemistry and Technology. ASPEN Publication, Maryland. 
Dexter, J.E. and Martin, D.G. (2002). The effects of wheat moisture content and reduction roll temperature and differential on the milling properties of Canadian hard red spring wheat. Association of Operative Millers - Bulletin (July): 7807-7814.

Dhingra, S. and Jood, S. (2004). Effect of flour blending on functional, baking and organoleptic characteristics of bread. International Journal of Food Science and Technology, 39: 213-222.

Douglas, S.C. (1981). A rapid method for the determination of pentosans in wheat flour. Food Chemistry. 7:139-145.

Eriksson, J. (2012). Barley starch, structure and properties. Master thesis. Faculty of Natural Resources and Agricultural Sciences. Swedish university of agriculture science.

Fast, R.B. and Caldwell, E.F. (2000) Breakfast Cereals and How They Are Made, 2nd edn. American Association of Cereal Chemists, St. Paul.

Gangopadhyay, N.; Hossain, M.B.; Rai, D.K. and Brunton, N. P. (2015). A Review of extraction and analysis of bioactives in oat and barley and scope for use of novel food processing technologies. Molecules, 20: 10884-10909.

Gray, D.; Abdel-Aal, E.M.; Seetharaman, K. and Kakuda, Y. (2010). Differences in viscosity and textural properties of selected barley cultivars as influenced by pearling and cooking. Food Chemistry, 120: 402-409.

Higley, J.S.; Love, S.L.; Price, W.J.; Nelson, J.E. and Huber, K.C. (2003). The rapid visco analyzer (RVA) as a tool for differentiating potato cultivars on the basis of flour pasting properties. American
Journal of Potato Research, 80:195-206.

Hironaka, R.; Beauchemin, K.A. and Lysyk, T.J. (1992). The effect of thickness of steam-rolled barley on its utilization by beef cattle. Canadian Journal of Animal Science, 72:279-286.

Holtekjølen, A.K.; Uhlen, A.K.; Bráthen, E.; Sahlstrøm, S. and Knutsen, S.H. (2006). Contents of starch and non-starch polysaccharides in barley varieties of different origin. Food Chemistry, 94: 348-358.

Hug-Iten, S.; Escher, F. and CondePetit, B. (2003). Staling of bread: role of amylose and amylopectin and influence of starch degrading enzymes. Cereal Chemistry, 80(6): 654-661.

Izydorczyk, M.S.; Dexter, J.E.; Desjardin, R.G.; Rossnagel, B.G.; Lagasse, S.L. and Hatcher, D.W. (2003). Roller milling of Canadian hull-less barley: optimization of roller milling conditions and composition of mill streams. Cereal Chemistry 80, 637-644.

Izydorczyk, M.S.; Storsley, J.; Labossiere, D.; MacGregor, A.W. and Rossnagel, B.G. (2000). Variation in total and soluble b-glucan content in hulless barley: Effects of thermal, physical, and enzymic treatments. Journal of Agricultural and Food Chemistry, 48: 982-989.

Kent-Jones, D.W, and Amos, A.J. (1957). Modern Cereal Chemistry. $5^{\text {th }}$ ed. Northern publishing, Co. Ltd. Liverpool.

Kent-Jons, D.W. and Amos, A.J. (1967). Conditioning and the effect of heat on wheat and flour. In "Modern Cereal Chemistry". $6^{\text {th }}$ ed. The Northern Publishing Co. Ltd. Liverpool England, pp. 166178.

Klamczynski, A.P. and Czuchajowska, 
Z. (1999). Quality of flours from waxy and non waxy barley for production of baked products. Cereal Chemistry, 76: 530-535.

Kleinwächter, M.; Müller, C.; Methner, F.J. and Silmar, D. (2014). Biochemical heterogeneity of malt is caused by both biological variation and differences in processing:

I. Individual grain analyses of biochemical parameters in differently steeped barley (Hordeum vulgare L.) malts. Food Chemistry, 147:25-33.

Kulp, K. and Lorenz, K. (1981). Heatmoisture treatment of starches. I. physicochemical properties. Cereal Chemistry, 58(1): 46-48.

Lowry, O.H.; Rosebrough, N.J.; Farr A.L. and Randall, R.J. (1951). Protein Measurement with the Folin Phenol Reagent. The Journal of Biological Chemistry, 193:265275

Maillard, M.N.; Soum, M. H., Boivin, P. and Berset, C. (1996). Antioxidant activity of barley and malt: Relationship with phenolic content. Lebensmittel Wissenschaft und Technologie, 29:238-244.

Maillared, M.E. and Berset, E. (1995). Evolution of the antioxidant activity during kilning: The role of insoluble and bound phenolic acids of barley and malt. Journal of Agriculture and Food Chemistry, 43:1789-1793.

McCleary, B.V. and Glennie, H.M. (1985). Enzymatic quantification of $(1 / 3),(1 / 4)-\beta$ - $D$-glucan in barley and malt. Journal of Institute of Brewing, 91:285-295.

Moundras, C.; Behr, S.R.; ReÂmeÂsy, C. and Demigne $\hat{A}, C$., (1997). Fecal losses of sterols and bile acids induced by feeding rats guar gum are due to greater pool size and liver bile acid secretion. Journal of Nutrition, 127: 1068-1076.
Oliver, J.R.; Blakeney, A.B. and Allen, H.M. (1993). The colour of flour streams as related to ash and pigment contents. Journal of Cereal Science, 17(2):169-182.

Ormerod, A.; Ralfs, J.; Jobling, S. and Gidley, M. (2002). The influence of starch swelling on the material properties of cooked potatoes. Journal of Mater Science, 37:1667-1673.

Östman, E.; Rossi, E.; Larsson, H.; Brighenti, F.; Björck, I. (2007). Glucose and insulin responses in healthy men to barley bread with different levels of $(1 / 3 ; 1 / 4)-\beta$ glucans; predictions using fluidity measurements of in vitro enzyme digests. Journal of Cereal Science, 43:230-235.

Othmann, A.Z. and Barghash, R. (2015). A comparative economic study of wheat production under terrace and traditional farming system in Sharkia governorate in Egypt. American-Eurasian Journal of Sustainable Agriculture, 9(4): 1-7.

Pasquier, B.; Armand, M.; Castelain, C.; Guillon, F.; Borel, P.; Lafont, H. and Lairon, D. (1996). Emulsi ${ }^{\circledR}$ cation and lipolysis of triacylglycerols are altered by viscous soluble dietary $§$ bre in acidic gastric medium in vitro. Biochemical Jurnal, 314: 269-275.

Preedy, V.R.; Watson, R.R. and Patel, V.B. (2011). Flour and Breads and their Fortification in Health and Disease Prevention. Academic Press is an imprint of Elsevier.

Quinde, Z., Ullrich, S.E. and Baik, B.K. (2004). Genotypic variation in color and discolouration potential of barley-based food products. Cereal Chemistry, 81: 752-758.

Reddy, M.; Reddy, R.; Prasad, R.P. and Munilakshmi, U. (2014). Grain 
and milling quality of barley and their suitability for preparation of traditional south Indian products. International Organization of Scientific Research (IOSR) Journal of Pharmacy, 4(2):23-27.

Richter, M.; Augustat, S. and Schierbaum, F. (1968). Ausgewählte Methoden der Stärkechemie. Wiss. Verlagsgesellschaft Stuttgart. (In German).

Sharma, P. and Gujral, H.S. (2010). Milling behavior of hulled barley and its thermal and pasting properties. Journal of Food Engineering, 97(3):329-334.

Singleton, V.L., and Rossi, J.A. (1965). Colorimetry of total phenolics with phosphomolybdicphosphotungstic acid reagent. American Journal of Enology and Viticulture, 16: 144-158.

Skendi, A. and Biliaderis, C.G.(2016). Gelation of wheat arabinoxylans in the presence of $\mathrm{Cu}^{+2}$ and in aqueous mixtures with cereal $\beta$ glucans. Food Chemistry, 203: 267-275.

Srinivasan, R. and Smith, K. (2012). Additional wet milling step for fractionation of barley flour after hull separation. Journal of Cereal Science, 56(2): 248-252.

Šubarić, D.; Babić, J.; Lalić, A.; Ačkar, Đ. and Kopjar, M. (2011). Isolation and characterisation of starch from different barley and oat varieties. Czech Journal of Food Sciences, 29(4): 354-360.

Swanson, R.B. and Penfield, M.P. (1988). Barley flour level and salt level selection for a whole-grain bread formula. Journal of Food Science, 53:896-901.

Tang, M.C., and Copeland, L. (2007). Analysis of complexes between lipids and wheat starch. Carbohydrate Polymers, 67:80-85.

Wang, P.; Tao, H.; Jin, Z. and Xu, X. (2016). Impact of water extractable arabinoxylan from rye bran on the frozen steamed bread dough quality. Food Chemistry, 200:117-124.

Zheng, X.; Li, L. and Wang, Q. (2011). Distribution and molecular characterization of $\beta$-glucans from hull-less barley bran, shorts and flour. International Journal of Molecular Sciences, 12:1563-1574. 
محتوى رطوبة مختلفة لتكييف حبوب الشعير المغطى و العاري قبل عملية الطحن 1- التأثير على معدل الاستخلاص و واللون وخصائص ولئ الدقيق

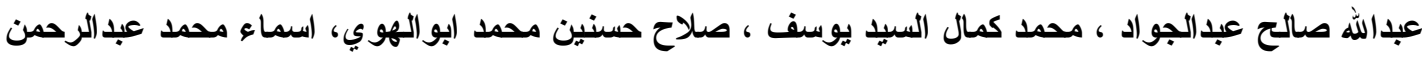

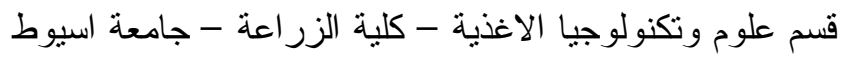

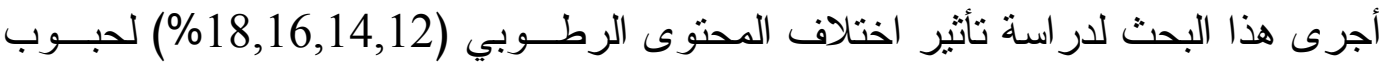

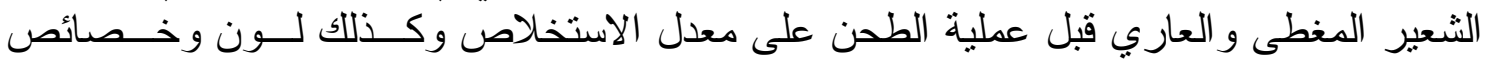

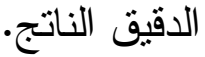

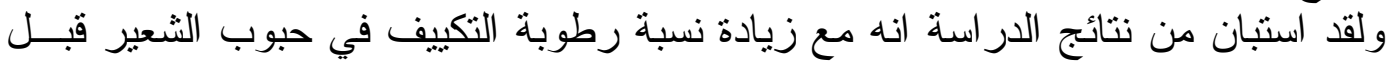

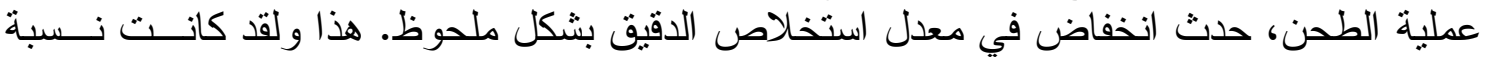

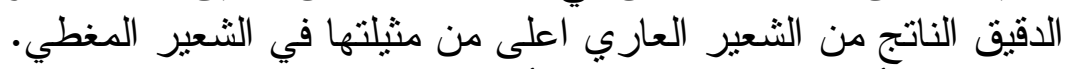

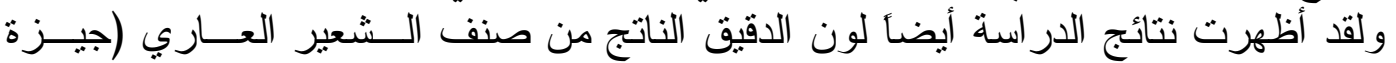

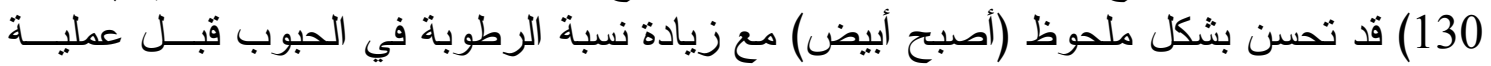

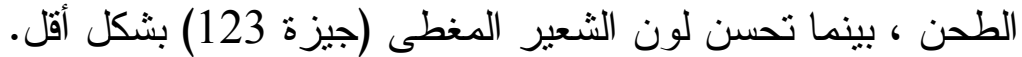

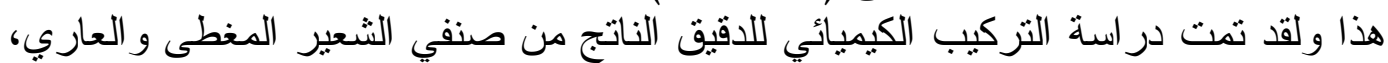

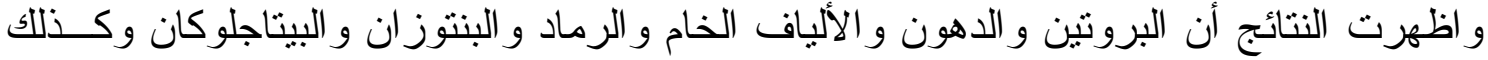

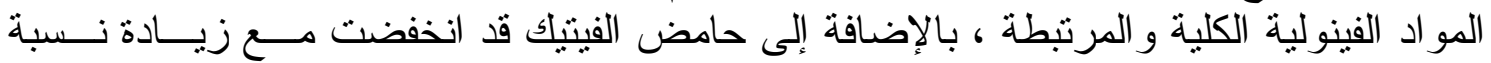
الرطوبة في حبوب الثعبير قبل عملية الطحن.

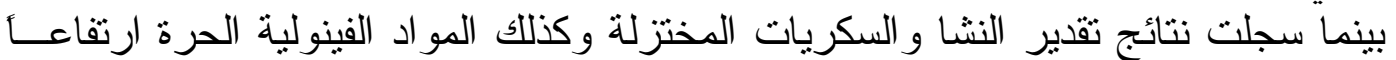

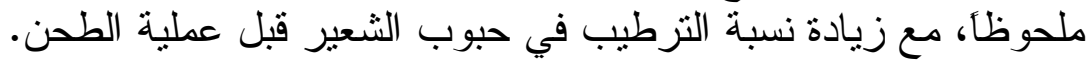

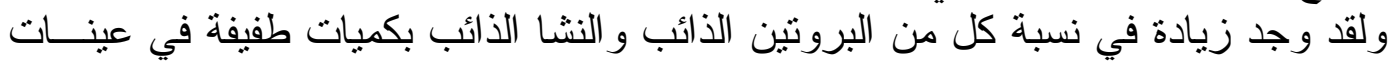

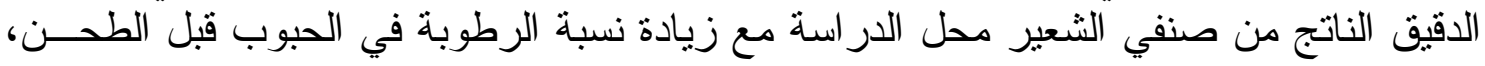

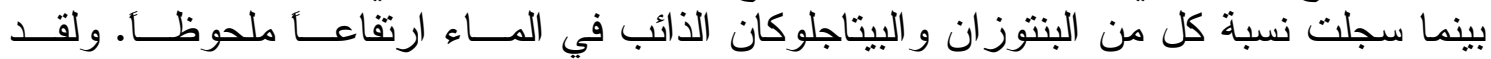

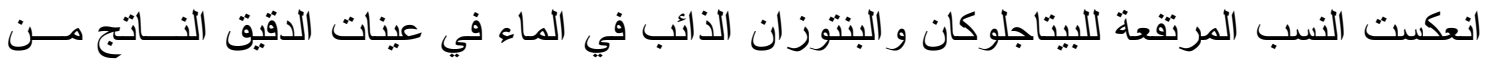

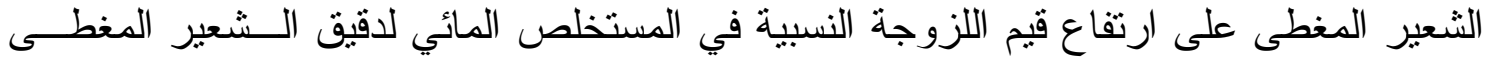
عن مثيلتها في الثعير العاري.

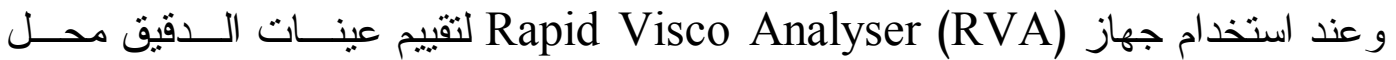

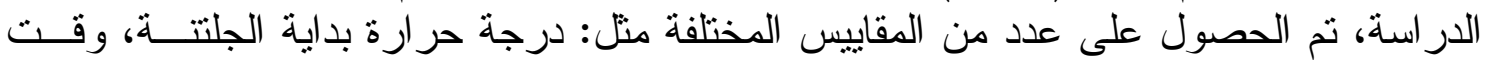

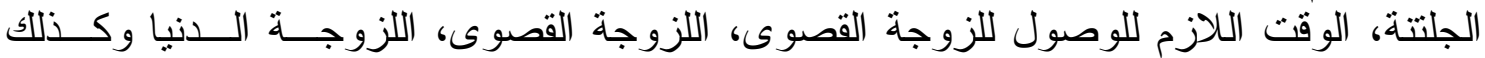

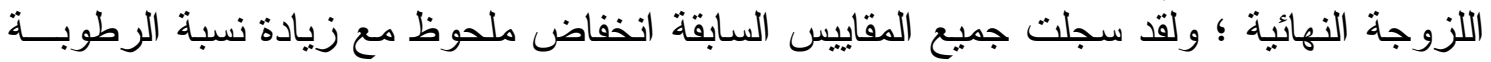
في حبوب الثُعير قبل عملية الطحن. 